\title{
Modeling Of Infectious Disease Through The Contact, Treatment And Recovery Of Chicken Pox Patients \\ (A Case Study Of Offa Local Government Area Of Kwara State )
}

\author{
Okeniyi O.M, Adeoye O.A, Ojo O.D, Adewoye K.B
}

\begin{abstract}
The outbreak and spread of diseases have been studied for many years. The ability to make predictions about diseases could enable scientists to evaluate inoculation/vaccination or isolation plans and may have a significant effect on the mortality rate of a particular epidemic. Therefore this research Modeling of Infectious Disease Through the Contact, Treatment And Recovery of Chicken Pox Patients (a case study of offa local government ) will study how people contact chickenpox and investigate how many people an infected person can infect at a particular time and to develop model for male and female with Chicken pox . Regression analysis, Chi - square and R0 in SIR model were use to analyse the data. Result of the analysis revealed that the rate at which people contact chickenpox will be increasing and that contact of chickenpox is not depended on gender. Regression analysis shows that the model for male is $Y=6,102+0.059 X$ and model for female is $Y=5.177+0.078 X$ and both model fitted the data. Further analysis revealed that, since R0 (Reproductive Number ) greater than 1 there will be likely epidemic on chickenpox for male and that $5.9 \%$ of the male that have chickenpox must be treated to avoid epidemics and also $7.8 \%$ of the female that have chickenpox must be treated to avoid epidemics. We thereby recommend that health planner should educate people more on chickenpox and the preventive measures.
\end{abstract}

Index Terms - Modeling, Treatment, Patients and chickenpox.

\section{INTRODUCTION}

Mathematical models represent the examined systems in the form of mathematical objects and their relationships, often in the form of various types of (dynamic) equations, or in the form of governing rules assembled as computer algorithms. Unfortunately, only the simplest mathematical models are analytically tractable (that is, can be completely solved using standard tools of mathematical analysis)[2]. As model complexity increases, what can usually be obtained are numerical solutions corresponding to specific initial conditions. For models of intermediate complexity, analytical tools and numerical simulations are standard combination and they complement one another. Whether formally analyzed or run as numerical simulation, mathematical models are useful experimental tools for building and testing theories, generating hypotheses, assessing quantitative conjectures, answering specific questions, determining system sensitivity

Okeniyi O.M, Adeoye O.A, Ojo O.D, Adewoye K.B, Department of Mathematics and Statistics Federal Polytechnic Offa to changes in parameter values and estimating key parameters from data. Models often identify behaviors that are unclear in experimental data most often because such data are hardly reproducible and the number of data points is often limited and subjected to measurement errors[3]. From the applied perspective, models can be used to supplant experiments that we, for some reasons, cannot conduct practically, and/or to assess and compare various management actions before they are actually employed. Any model is necessarily a simplified representation of reality, one is always forced to prioritize, that is, consider only those aspects of the examined system, which are essential for its understanding and/or prediction of its behavior and neglect those aspects that seem marginal for the question of interest. As a result, no model can be considered the best one; there is always a basis for improvement, no matter how small/little[1]. Infectious disease is the result of a convergence of social, political, and economic factors, whether the diseases are new, re-emerging, or becoming endemic. Societal decisions and actions, or lack of such can have unintended consequences that cause emerging infectious disease to flourish, harming local populations and potentially the global community.

Chickenpox is a highly contagious disease that is caused by the initial infection with varicella zoster virus (VZV), the disease result in characteristic skin rashes that form small itchy blister, which eventually scab over human body surface[4]. This usually starts on the chest, back and face before it spread to the remaining part of the body chicken pox and herpes zoster worldwide. Before routine immunization the number of cases occurring each year was similar to the number of people born. Since immunization the number of infections in the United States has decreased nearly $90 \%$. In 2015 chickenpox resulted in 6,400 deaths globally - down from 8,900 in 1990. Chickenpox is an airborne disease which spreads easily through coughs and sneezes of the affected ones. It may spread from one to two days before the rashes appear until all lesions have crusted over and it may also spread through contact with the blister. Those with shingles may spread chicken to those who are not immune through contact with the blisters[5].

Chickenpox may be suspected to occur in human body through some symptoms like fever, tiredness, headaches and this may occur repeatedly for five to seven days before the appearance of the blisters. Non-immune pregnant women and those with a suppressed immune system are at highest risk of serious complications. Arterial ischemic stroke (AIS) 
associated with chickenpox in the previous year accounts for nearly one third of childhood AIS. The most common late complication of chickenpox is shingles (herpes zoster), caused by reactivation of the varicella zoster virus decades after the initial, often childhood, chickenpox infection. Previous research shows that before the introduction of chickenpox vaccine immunization, the number of cases occurring each year was similar to the number of people born. The chickenpox vaccine, also known as the varicella vaccine (Varivax, Merck), is a live, attenuated vaccine made from the Oka strain of the varicella zoster virus.

\section{RESEARCH METHODOLOGY}

\section{DATA COLLECTION}

Use of Questionnaire was adopted as follows

$>$ Pilot survey

$>$ Proper Survey

$>$ Post enumeration survey

\section{METHOD OF DATA COLLECTION}

The method of data collection refers to the method used in obtaining the information required. Before acquiring the data used for this research work, the population of Offa local government was sampled out based on stratified sampling technique in which the population was grouped homogeneously by grouping them based on each political wards in offa local government of Kwara state. The political wards include Balogun ward, Essa ward A, Essa ward B, Essa ward C, Igboidun, Ojomu centre A, Ojomu centre B, Ojomu north, Shawo centre, Shawo south A, Shawo south B and questionnaires were administered within this political wards and collected, in which proper analysis was carried out on the questionnaires.

\section{METHOD OF DATA ANALYSIS}

The statistical technique used for analyzing the collected data for this research work was CHI SQUARE $\left(\chi^{2}\right)$. Chi square is a non parametric statistics which is usually apply in a test involving nominal measurement. It is use to test the independent of two traits or correlation. It is also use to test for goodness fit of statistics frequency, measures etc. This area of the research work will mainly deal with the gender contact of chickenpox within the wards in Offa local government. The necessary computation formula is $\mathrm{X}^{2}=\sum \frac{\left(O_{i j}-E_{i j}\right)^{2}}{E_{i j}}$

Where $\mathrm{O}_{\mathrm{ij}}$ - the observed value

$$
\mathrm{E}_{\mathrm{ij}} \text { - the expected value }
$$

To calculate expected frequencies, it is estimated by multiplying the sum of each row by the sum of each column and the product divided by the grand total

$$
\mathrm{E}_{\mathrm{ij}}=\frac{\text { row total } \times \text { column total }}{\text { grand total }}
$$

State the Hypothesis to be use

$\mathrm{H}_{0}$ : Gender is independent of contact and treatment of chickenpox

$\mathrm{H}_{1}$ : Gender is dependent of contact and treatment of chickenpox

Level of significance $\quad \alpha=0.05$

Test statistic: $\mathrm{X}^{2}=\sum \frac{\left(O_{i j}-E_{i j}\right)^{2}}{E_{i j}}$

\section{REGRESSION}

Linear regression is an approach to modelling the relationship between a scalar dependent variable $\boldsymbol{y}$ and one or more explanatory variables denoted $x$. The case of one explanatory variable is called simple regression. More than one explanatory variable is multiple regressions.

The linear regression model, with infinite response variables, is given by:

$$
y_{i}=\beta_{0}+\beta_{1} x_{1 i}+\beta_{2} x_{2 i}+, \ldots,+\varepsilon_{i}
$$

$R_{0}=\frac{\beta N}{\gamma}$ where Ro represent basic reproductive number

\section{DATA ANALYSIS}

Chi square tests of independence were carried out on few of the questions in the administered questionnaires which correspond to some hypotheses. The following hypotheses were test;

\section{TEST OF HYPOTHESIS I}

\section{TEST OF HYPOTHESIS USING CHI-SQUARE}

$\mathrm{H}_{0}$ : contacting chickenpox is independent of gender.

$\mathrm{H}_{1}$ : contacting chickenpox is dependent of gender.

$$
\text { TEST STATISTIC: } \mathrm{X}^{2}=\sum \frac{\left(O_{i j}-E_{i j}\right)^{2}}{E_{i j}}
$$

CRITICAL VALUE $\alpha=0.05$

DECISION RULE: Reject $\mathrm{H}_{0}$ if $\mathrm{P}$-value $<$ critical value $(\alpha)$, if otherwise do not reject $\mathrm{H}_{0}$.

\section{COMPUTATION}

The rows and columns of the contingency table below shows the data collected from both male and female respondents on the number of those that have had chickenpox. Table.1 gender * have you ever had chickenpox

\begin{tabular}{|ll|l|l|l|}
\hline \multirow{2}{*}{} & & \multicolumn{2}{|l|}{ have you ever had chickenpox } & Total \\
\cline { 3 - 4 } & Yes & No & \\
\hline \multirow{2}{*}{ Gender } & Male & 1727 & 1328 & 3055 \\
\multirow{2}{*}{ Total } & Female & 1411 & 1009 & 2420 \\
& 3138 & 2337 & 5475 \\
\hline
\end{tabular}

Source: Survey 2018 by Okeniyi O.M „Adeoye O.A , Ojo O

\begin{tabular}{|c|c|c|c|c|}
\hline & Value & Df & $\begin{array}{l}\text { Asymp. Sig. } \\
\text { (2-sided) }\end{array}$ & $\begin{array}{l}\text { Exact Sig. } \\
\text { (2-sided) }\end{array}$ \\
\hline $\begin{array}{l}\text { Pearson } \\
\text { Chi-Square } \\
\text { Continuity } \\
\text { Correction } \\
\text { Likelihood Ratio } \\
\text { Fisher's Exact Test } \\
\text { Linear-by-Linear } \\
\text { Association } \\
\mathrm{N} \text { of Valid Cases }\end{array}$ & $\begin{array}{l}28.411^{\mathrm{a}} \\
26.433 \\
29.331 \\
28.237 \\
5475\end{array}$ & $\begin{array}{l}1 \\
1\end{array}$ & $\begin{array}{l}.080 \\
.060 \\
.070 \\
.070\end{array}$ & .060 \\
\hline
\end{tabular}
.D and Adewoye K.B

Table 2 Chi-Square test on those that have ever had chickenpox

Source: Survey 2018 by Okeniyi O.M „Adeoye O.A , Ojo O .D and Adewoye K.B

CONCLUSION: Since P-value (0.06) < Critical value (0.05), do not reject $\mathrm{H}_{0}$ and conclude that contacting chickenpox is independent of gender. 
TEST OF HYPOTHESIS USING CHI-SQUARE

$\mathrm{H}_{0}$ : Age when chickenpox was contacted is independent of gender

$\mathrm{H}_{1}$ : Age when chickenpox was contacted is dependent of gender

TEST STATISTIC: $\mathrm{X}^{2}=\sum \frac{\left(O_{i j}-E_{i j}\right)^{2}}{E_{i j}}$
CRITICAL VALUE $\quad \alpha=0.05$

DECISION RULE: Reject $\mathrm{H}_{0}$ if $\mathrm{P}$-value $<$ critical value $(\alpha)$, if otherwise do not reject.

COMPUTATION The rows and columns of the contingency table below shows the data collected from both male and female respondents on the age at which the respondent had chickenpox.

Table 3 Chi-Square test on the age the respondents were when contacted chickenpox

\begin{tabular}{|l|l|l|l|l|}
\hline & Value & $\begin{array}{l}\mathrm{D} \\
\mathrm{f}\end{array}$ & $\begin{array}{l}\text { Asymp. } \\
\text { Sig. } \\
(2 \text {-sided })\end{array}$ & $\begin{array}{l}\text { Exact Sig. } \\
(2 \text {-sided })\end{array}$ \\
\hline $\begin{array}{l}\text { Pearson Chi-Square } \\
\text { Continuity Correction }\end{array}$ & $.180^{\mathrm{a}}$ & 1 & .672 & \\
$\begin{array}{l}\text { Likelihood Ratio } \\
\text { Fisher's Exact Test }\end{array}$ & .000 & 1 & .989 & \\
$\begin{array}{l}\text { Linear-by-Linear } \\
\text { Association }\end{array}$ & 175 & .675 & .696 \\
N of Valid Cases & 93 & 1 & .673 & \\
\hline
\end{tabular}

Source: Survey 2018 by Okeniyi O.M „Adeoye O.A, Ojo O .D and Adewoye K.B

Conclusion: since P-value $(0.696)$ < Critical value $(0.05)$, we do not reject $\mathrm{H}_{0}$ and conclude that Age when chickenpox was contacted is independent of gender.

Table 4 : Shows the male model on chickenpox

\begin{tabular}{|lc|l|l|l|l|}
\hline \multirow{2}{*}{ Model } & \multicolumn{2}{|l|}{ Unstandardized Coefficients } & \multirow{2}{*}{ T } & Sig. \\
\cline { 2 - 3 } & $\mathrm{B}$ & Std. Error & & \\
\hline \multirow{2}{*}{$\begin{array}{l}\text { 1 } \\
\text { Constant }\end{array}$} & 6.102 & 4.210 & -2.961 & .000 \\
& MALE & 0.059 & .042 & 10.807 & .000 \\
\hline
\end{tabular}

Source: Survey 2018 by Okeniyi O.M „Adeoye O.A, Ojo O .D and Adewoye K.B

The model is $\mathrm{Y}=6.102+0.059 \mathrm{X}$ for the male

Table 5 : Shows the Female model on chickenpox

\begin{tabular}{|ll|l|l|l|l|}
\hline & & \multicolumn{2}{|c|}{ T } & Sig. \\
\cline { 3 - 4 } & & $\mathrm{B}$ & Std. Error & & \\
\hline \multirow{2}{*}{1} & (Constant) & 5.177 & 4.086 & -10.3 & .02 \\
& FEMALE & 0.078 & .0145 & 12.0 & .01 \\
\hline
\end{tabular}

Source: Survey 2018 by Source: Survey 2018 by Okeniyi O.M „Adeoye O.A , Ojo O .D and Adewoye K.B

The model is $\mathrm{Y}=5.177+0.078 \mathrm{X}$ for the Female

Table 6: Shows the reproductive number of male and female

\begin{tabular}{|l|l|l|l|}
\hline & $\mathrm{B}$ & $\Gamma$ & $\mathrm{R}_{0}$ \\
\hline Male & 0.059 & 7 & 25.75 \\
\hline Female & 0.078 & 7 & 26.96 \\
\hline
\end{tabular}

Source: Survey 2017 by Source: Survey 2018 by Okeniyi O.M „Adeoye O.A , Ojo O .D and Adewoye K.B

Since $\mathrm{R}_{0}$ greater than 1 there will be likely epidemic on chickenpox and that $5.9 \%$ of the male that have chickenpox must be treated to avoid epidemics $7.8 \%$ of the female that have chicken must be treated to avoid epidemics.

\section{GENERAL CONCLUSION}

The aim of this research work is to know the rate at which chickenpox spread and the time to cure it in Offa local Government of Kwara State. The method that was employed in collecting the data is questionnaire method. Questionnaires were administered to some selected people from all the political wards of Offa Local Government in Kwara state and were retrieved for further analysis. The methods of data analysis used were data exploration, Chi-Square test and regression .

Based on the analysis carried out in this research work, it was discovered that contact of chickenpox is independent of gender. Meanwhile, the analysis carried out on the time it takes for chickenpox to spread against gender of the respondents showed the time for chickenpox to spread is independent of gender. It was also observed from the analysis that the number of days for chickenpox to get cured is independent of gender.

Result of the analysis revealed that the rate at which people contact chickenpox will be increasing and also revealed that contact of chickenpox is not depended on gender. Moreover there are differences in the health status of chickenpox patient when taking drugs recommended by health workers. Regression analysis shows that the model for male is $\mathrm{Y}=$ $6,102+0.059 \mathrm{X}$ and model for female is $\mathrm{Y}=5.177+0.078 \mathrm{X}$ and both model fitted the data. Further analysis revealed that since $\mathrm{R}_{0}$ (Reproductive Number ) greater than 1 there will be likely epidemic on chickenpox for male and that $5.9 \%$ of the male that have chickenpox must be treated to avoid epidemics and also $7.8 \%$ of the female that have chickenpox must be treated to avoid epidemics.

\section{Recommendation}

1. Health Planner should educate people more on chickenpox and the preventive measures.

2. Health Planner should administer enough drugs to chickenpox patient on regular basis.

3. Government at federal, states and local government should encourage chickenpox patient to present themselves for test.

4. All agencies involve in educating the masses on chickenpox should be funded adequately.

5. Government at federal, states, and local government should embark on a massive enlightenments and awareness at rural areas were $70 \%$ of the

population resides.More skill workers be engage as care and support group

\section{REFERENCES}

[1] R. Naresh, S. Panduy, and A.K. Misra,(2008) Analysis of Vaccination model for carrier dependent infectious diseases with environmental effects. Journal of Non-linear Analysis: Modeling and control, 13 (3), 2008, 331-350.

[2] C.P. Farrington,(2003) On Vaccine Efficacy and Reproduction numbers, Journal of Mathematics and Bioscience, 185, 2003 89-109.

[3] A.B. Gumel, and S.M. Moghadas,(2003) A qualitative Study of a Vaccination Model with Non-Linear Incidence. Journal of Appl. Math.Comp, 143, 2003, 409-419.

[4] C.M. Kribs-Zaleta, J.X. Velasco-Hernandez, A Simple Vaccination Model With Multiple Epidemic States, Math. Biosc. 164, 2000,183-201.

[5] B. shulgin, L. Stone, Z. Agur,(1998) Pulse Vaccination Strategy in the SIR Epidemic Model. Bull Math. Biol. (1998) 60, pp. 1123-1148. 